age, far antedate any of the previously known examples of Homo sapiens, to which dates not earlier than the end of the Ice Age have been assigned. On the other hand, he holds that the Kanam fragment of mandible, being of early Pleistocene age, is of the same high order of antiquity as Java, Peking and Piltdown man. Dr. Leakey will submit his conclusions to the Royal Anthropological Institute in a lecture on "The Status of the Kanjera Skulls and the Kanam Mandible" to be delivered on October 20 at 5.30 p.m., when Prof. Elliot Smith will take the chair.

\section{Romano-British Pottery at Colchester}

FURTHER details of the interesting finds of Roman potters' kilns at Colchester are given in an article in the Times of October 10 which marks the close of the Colchester Excavation Committee's work for the season. Since comparatively little is known about the detail of the manufacture of 'Samian' pottery in Britain, the find is of considerable importance. A series of eight kilns was discovered. Four of the kilns, widely spaced, had been used for jugs, mortaria and other vessels in coarse buff ware. The second four kilns were concentrated in a narrow area surrounded by a retaining wall and buried 5-8 ft. deep beneath a mass of material in which the numerous fragments of 'Samian' moulds and ware made it evident beyond question that this was the place of manufacture of the 'Samian' ware. The material in the largest kiln, $14 \mathrm{ft}$. long, had been fused by overfiring. Not only were the two types, the old-style British and the 'Samian', mass production articles, found where they had been made, side by side, but also the stamps of the 'Samian' ware bore well-known names of potters whose factories are known in eastern Gaul and Germany. These are repeated on the colour-coated 'Castor' ware, decorated with applied hunting scenes, which was also made at Colchester. These stamps and the similarities of form and moulds linking them up with examples of known date from the Continent, afford sure criteria for fixing a date, which is corroborated by the find of a coin of Marcus Aurelius, at about A.D. 180 to 200 .

\section{Significance of Anthropological Studies in Modern Civil-} isation

A coorse of eleven public lectures on "The Study of Man" will be delivered at University College in the University of London during the coming session. The lectures will have a topical interest in a somewhat unusual sense. Their aim will be to present aspects of the subject-matter of the science of anthropology as a study of the methods by which man in the past and also backward peoples have approached the problems of life; but more especially they will suggest the practical bearing of the principles governing human actions and reactions, revealed by anthropological studies, in the solution of like problems which arise in modern civilisation. The opening lecture, on "The Practical Value of Human Studies", will be delivered by Mr. F. J. Richards, honorary lecturer in Indian archæology.
Prof. Charles Singer will follow on "The Develop. ment of the Study of Man". The remaining lecturers will be: Prof. C. B. Fawcett, on "Geographical Factors in the Study of Man" ; Dr. R. E. M. Wheeler, on "Early Civilisation and Economics"; Dr. Margaret Murray, on "Religion and Ritual in the Study of Man"; Prof. B. Ashmole, on "The Place of Art in the Study of Man"; Mr. S. R. K. Glanville, on "The Eastern Origin of Western Civilisation" ; Dr. R. E. M. Wheeler, on "Race and History in Ancient Europe" ; Dr. L. W. G. Malcolm, on "Africa, Past and Present"; Mr. A. M. Hocart, on "The South Seas, the Organisation of Peoples" ; and Mr. K. de B. Codrington, on "India, the Village as a Social Unit". The lectures will be delivered at University College, Gower Street, W.C., on each Monday in term at 5.30 p.m., beginning on Monday next, October 16. The chair at the first lecture will be taken by the Provost, Dr. Allen Mawer.

\section{Chemistry, Philosophy and Food Values}

IT is evidence of vigour of both mind and body when a man who can say that he saw the Great Eastern upon the stocks, before she sailed west to lay the first Atlantic cable, is able to deliver an address of an hour's duration which will hold an audience largely composed of students. Prof. Henry E. Armstrong is, however, known in the world of chemistry as one whom the years pass lightly by. His mind is as intellectually alert, critical and unrepentant to-day as at any time during his long career. The address which he gave at the opening of the College of the Pharmaceutical Society on October 4 contains passages of caustic comment mixed with others of no less delightful charm, which illustrate as much his philosophy of life as his outlook upon his own profession. It makes stimulating reading. Although some may smile as here and there they detect echoes of opinions which the author has made peculiarly his own, yet the address emphasised a truth that can never be overstated: that it is essential that philosophical theorising shall proceed side by side with the practical experiments of the laboratory, without which there can be no sure progress.

Some flowers from Prof. Armstrong's collection may be preserved. His first chemical appointment he chronicles in the words:- "I mounted the professional dunghill in the autumn of 1870 at the London Institution, Finsbury Circus". Of Bentley, whose services to botany were mainly in the realm of classification, he says :- "He was certainly a character, but he knew his plants, an accusation that can be brought against few botanists to-day", and upon the trend of modern chemical thought towards mathematics and away from the laboratory, his comment is:- "Of late years the clerical mind has again ruled us; chemistry has suffered a neophilogistic outburst. Oxygen has gone out of fashion, its place taken by a beautiful myth, as elusive as phlogiston, the hydrogen ion, a creation of Leipzig journalism, never born of science, but only guesswork". He is critical of the fads of the researcher 